\title{
THE EFFECTS OF ORGANIC LAKE SEDIMENTS ON THE CROP ROTATION YIELD AND SOIL CHARACTERISTICS IN SOUTHEAST LITHUANIA
}

\author{
BAKSIENE, E. - ASAKAVICIUTE, R.* \\ Voke Branch of Lithuanian Research Centre for Agriculture and Forestry \\ Žalioji aikštè 2, Traku Voke, LT-02232 Vilnius, Lithuania \\ (phone: +370-5-264-5439; fax: +370-5-264-5430) \\ *Corresponding author \\ e-mail: rita.asakaviciute@voke.lzi.lt \\ (Received $17^{\text {th }}$ June 2011; accepted $5^{\text {th }}$ September 2013)
}

\begin{abstract}
In the silty Lithuanian lakes are accumulated about 1,5 mlrd. $\mathrm{m}^{3}$ sediments. It is valuable organic matter, which can be used for fertilization and improving of soil. The experiments with the purpose to study the possibilities to use lake sediments for improvement infertile environmental object sandy loam Cambisol were carried out at the Voke Branch of the Lithuanian Research Centre for Agriculture and Forestry. The investigations on the efficiency of organic lake sediments were conducted on the background containing no mineral fertilizers and in the one with minimum rates of $\mathrm{N}_{30-60} \mathrm{P}_{30-40} \mathrm{~K}_{50}$ ${ }_{60}$ mineral fertilizers according to the following scheme: in 1999-2009. Results confirm that fertilization of soil with various rates of organic lake sediments and its mixtures with manure and sewage influences the productivity of crop rotation (maize, maize (Zea mays L.), barley (Hordeum L.), with under-crop, perennial grasses (Trifolium pratense L. and Pheleum pratense L.) of the $1^{\text {st }}$ and $2^{\text {nd }}$ year of use, winter rye (Secale cereale L.) blend of oats and lupin (Avena sativa L. and Lupinus angustifolius L.), barley (Hordeum L.), with under-crop, perennial grasses (Trifolium pratense L. and Pheleum pratense L.), blend of oats and lupin, barley (Hordeum L.).
\end{abstract}

Keywords: lake sediments, manure, yield, soil, properties, fertilization

\section{Introduction}

It is very important to preserve organic soil material of light textured soils. Even if extensive agriculture is being carried on, the preservation of nutritious possible only with its gradual replenishment with organic fertilizers. With agriculture becoming more intensive and increasing production, humus is rapidly mineralised and the soil becomes exhausted (Loveland and Webb, 2003; Enters et al., 2008). One source of organic fertilizers are lake sediments. It abundantly accumulates in lakes situated in the regions with unproductive soils (Roberts, Brayshaw et al., 2011). The life of human beings caused water resources to be destroyed because of negative human life itself. Therefore natural eutrophication lakes and anthropological activity of people in an area of lakes, in the world many lakes are silty, they are decaying and turning into marsh (Adriaens et al., 2002; Shukla et al., 2010). The most attention is given to mechanical cleaning removal of sediments from the already silted lakes. Application of lakes sediments as fertilisers looks most appropriate (Alkan et al., 2009). If they are properly used come costs involved in the cleaning could return. Investigations carried out in France, Italy, Russian and United Kingdom countries on the effects of lake sediments allow us to suppose that its impact depends upon its chemical composition (Grishina et al., 1990; Andresini et al., 2003). Calcareous lake sediments are more suitable as a measure for soil liming, organic and siliceous ones are suitable as a source of nutritious materials (Orlov and Sadovnikova, 1996; Roberts, Eastwood et al., 2011). 
In Lithuania the efficiency of calcareous lake sediments has been investigated extensively. In sandy loam soil and sandy soil in crop rotation fields the rates of 50, 100, 150, and $200 \mathrm{t} \mathrm{ha}^{-1}$ (of dry matter) of calcareous sediments from Lake Ilgutis (Vilnius district) were investigated we tests various rates of sediments functioned as long-term measure of improved agrochemical and physical properties of soil. After fertilization with lake sediments, acidity of soil decreased, content of humus increased, and qualitative composition improved. All rates of sediments improved soil texture and moisture regime. However, various rates of calcareous sediments had no positive effect upon the productivity of crop rotation. The research results showed that the application of sediments in sandy loam soil $\left(\mathrm{pH}\right.$ 6.0) in the $1^{\text {st }}$ crop rotation season increased the yield of agricultural plants by $2-5 \%$. Only after application of the largest rate $(-200 \mathrm{t}$ $\mathrm{ha}^{-1)}$ of dry sediments - the productivity increased by $7 \%$ during the $2^{\text {nd }}$ crop rotation season. It may be predicated that sediments containing larger amount of organic material is more effective for the yield of agricultural plants (Baksiene and Janusiene, 2005).

According to Russian scientists, organic lake sediments are most effective. Having carried out field experiments they have determined that organic lake sediments were no less efficient than peat-manure compost in sandy loam soil, sometimes even superior. The rate of 60-80 $\mathrm{t} \mathrm{ha}^{-1}$ of sediments produced the additional yield of 0.34-1.61 $\mathrm{t} \mathrm{ha}^{-1}$ of barley, while the same rate of peat-manure compost produced the additional yield of 0.28-1.06 t ha ${ }^{-1}$ (Grigorov and Ovchinnikov, 1994; Trapeznikova, 2011). Practically all investigators agree that lake sediments function as long-term measure for improving agrochemical and physical properties of soil (Booth et al., 2007).

In Lithuania research on the possibilities to apply organic lake sediments for soil fertilization were started in 1999. Their aim was to determine the influence of various rates of lake sediments and its mixtures with other organic fertilizers (manure, sewage) and mineral NPK fertilizers upon the yield, agrochemical and physical characteristics of soil, to compare the efficiency of sediments with the one of manure and sedimentsmanure mixture.

\section{Materials and methods}

\section{Field experiments}

Experimental plots for the study of organic lake sediments were established in a field crop rotation (maize, maize (Zea mays L.), barley (Hordeum L.), with under-crop, perennial grasses (Trifolium pratense L. and Pheleum pratense L.) of the $1^{\text {st }}$ and $2^{\text {nd }}$ year of use, winter rye (Secale cereale L.) blend of oats and lupin (Avena sativa L. and Lupinus angustifolius L.), barley (Hordeum L.), with under-crop, perennial grasses (Trifolium pratense L. and Pheleum pratense L.), blend of oats and lupin, barley (Hordeum L.).

The investigations on the efficiency of organic lake sediments were conducted on the background containing no mineral fertilizers and in the one with minimum rates of $\mathrm{N}_{30}$ ${ }_{60} \mathrm{P}_{30-40} \mathrm{~K}_{50-60}$ mineral fertilizers according to the following scheme: 1 . Control; $2.10 \mathrm{t}$ $\mathrm{ha}^{-1}$ dry sediments (S); 3. $20 \mathrm{t} \mathrm{ha}^{-1}$ dry sediments (S); $4.40 \mathrm{t} \mathrm{ha}^{-1}$ dry sediments (S); 5. $10 \mathrm{t} \mathrm{ha}^{-1}$ dry sediments $(\mathrm{S})+10 \mathrm{t} \mathrm{ha}^{-1}$ manure $(\mathrm{M}) ; 6.10 \mathrm{t} \mathrm{ha}^{-1}$ dry sediments $(\mathrm{S})+25 \mathrm{t}$ $\mathrm{ha}^{-1}$ manure $(\mathrm{M}) ; 7.10 \mathrm{t} \mathrm{ha}^{-1}$ dry sediments $(\mathrm{S})+10 \mathrm{~m}^{3} \mathrm{ha}^{-1}$ sewage $(\mathrm{Se}) ; 8.65 \mathrm{t} \mathrm{ha}^{-1}$ manure (M). The sediments was taken from Lake Guobstas situated on the territory of 
Voke Branch $\left(54^{\circ} 49^{1} \mathrm{~N}, 25^{\circ} 10^{1} \mathrm{E}\right)$. Sediments humidity was $70-80 \%$. It contained: N3.29 , P-0.04, K-0.16, Ca-1.48, Mg-0.22 and $90 \%$ of organic mater in dry material.

Organic lake sediments, manure, and sewage were applied only in the period of establishment of experimental plots. Later the impact of the substances mentioned above was observed considering their influence upon the yield of plants grown in crop rotation and upon the changes of soil agrochemical and physical properties. Minimal rates of $\mathrm{N}_{30-60} \mathrm{P}_{30-40} \mathrm{~K}_{50-60}$ mineral fertilizers were spread every year before the time of plant sowing.

\section{Soil sampling}

The experimental plots were established in a rather neutral $\left(\mathrm{pH}_{\mathrm{KCl}}\right.$ 6.3-6.5) phosphorous-rich (152.2-189.2 mg kg-1 soil) and potassium-rich (170.0-191.2 mg kg-1 soil) humus (1.54-1.81\%) sandy loam Cambisol.

To identify changes in agrochemical soil properties samples were taken before the establishment of the experimental plots (in 1999) and after the crop rotation in 2009.

Soil bulk density, moisture, total and aeration porosity were measured annually after sowing in spring (I) and after harvesting in autumn (II) every year in 1999-2009 in treatments: (1.10 tha $\mathrm{ta}^{-1}$ of dry sediments (S);2. $40 \mathrm{t} \mathrm{ha}^{-1}$ of dry sediments (S); $3.10 \mathrm{t} \mathrm{ha}^{-}$ of dry sediments $(\mathrm{S})+25 \mathrm{t} \mathrm{ha}^{-1}$ of manure $(\mathrm{M}) ; 4.65 \mathrm{t} \mathrm{ha}^{-1}$ of manure (M).

\section{Analytical methods}

Soil properties were analysed using the following methods: $\mathrm{pH}_{\mathrm{KCl}}$ was determined in $1 \mathrm{M} \mathrm{KCl}$ soil sample extracts using a calibrated digital $\mathrm{pH}$ meter. Exchangeable bases were determined by the Kappen-Hilkovic method, which is based on hot titration of 0.1 $\mathrm{M} \mathrm{HCl}$ and soil sample filtrate (ratio sample: extract 1:5) with $0.1 \mathrm{M} \mathrm{NaOH}$ (Askinazi, 1975). Total N (\%) was determined by the Kjeldahl method, digested in $\mathrm{H}_{2} \mathrm{SO}_{4}$, distilled and titrated with $0.1 \mathrm{M} \mathrm{NaOH}$ (ISO 11261, 1995). Soil humus (\%) was determined by the Tiurin method (Orlov and Grisina, 1981), humified soil organic matter was oxidized using potassium dichromate with sulphuric acid, ratio 1:50 (25) and excess dichromate determined by titration with ferrous sulphate (Mohr solution). Available $\mathrm{P}_{2} \mathrm{O}_{5}$ and $\mathrm{K}_{2} \mathrm{O}$ $\left(\mathrm{mg} \mathrm{kg}^{-1}\right)$ were extracted with ammonium acetate-lactate A-L solution, $\mathrm{pH} \mathrm{3.7;} \mathrm{ratio}$ 1:20). Available $\mathrm{P}_{2} \mathrm{O}_{5}$ was determined by spectrophotometry and available $\mathrm{K}_{2} \mathrm{O}$ by flame photometry by the Egner-Riehm-Domingo method (Egner et al., 1960).

Soil bulk density, moisture, total and aeration porosity were estimated by the weighing method.

\section{Statistics}

Relative feed value (RFV) was calculated from predicted values for both dry matter intake (DMI) and digestible dry matter (DDM), based on laboratory analyses for neutral-detergent fibre (NDF) and acid-detergent fibre (ADF), respectively. The current equations used by the US National Forage Testing Association (NFTA) are: DMI, \% dry weight $=120 /(\mathrm{NDF}, \%$ of dry matter $) ; \mathrm{DDM}, \%$ dry matter $=88.9-0.779 \times(\mathrm{ADF}, \%$ of dry matter); RFV $=\mathrm{DMI} \times \mathrm{DDM} / 1.29$. The divisor 1.29 , was chosen so that the RFV of full bloom alfalfa has a value of 100 (Moore \& Undersander, 2002).

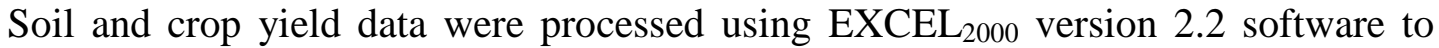
perform One-way Analysis of Variance. All data were evaluated according to Fisher criteria (F) and $\mathrm{LSD}_{05}$ (Brewbaker, 1995; Tarakanovas and Raudonius, 2003). 


\section{Results and discussion}

The research results show that of maize cultivation on both backgrounds of mineral fertilization sediments rates proportionally enlarged from 10 to $40 \mathrm{t} \mathrm{ha}^{-1}$ increased the yield of maize feed units from 2188-2695 to 3028-3255 accordingly. However, the best and most reliable additional yield (3885 and 4113 feed units) was obtained having applied the mixture of $10 \mathrm{t} \mathrm{ha}^{-1}$ sediments plus $25 \mathrm{tha}^{-1}$ manure (Table 1). The effect of minimal rates of mineral $\mathrm{N}_{60} \mathrm{P}_{40} \mathrm{~K}_{60}$ fertilizers was more evident for maize, in some cases the yield of feed units increased up to 728 (treatment 1).

Productivity of barley grain and straw was mostly effected by the rate of $40 \mathrm{t} \mathrm{ha}^{-1}$ lake sediments. On the background without mineral fertilisers reliable extra yield was 2120 feed units and on the background with minimal rates of organic $\mathrm{N}_{30} \mathrm{P}_{30} \mathrm{~K}_{50}$ fertilisers -4021 feed units. Under the impact of sediments-manure and sewage mixture the additional yield differed insignificantly, within the standard error.

Proper fertilization of soil also influenced the yield of grass. Although no statistically reliable additional yield was obtained, the yield of perennial grass of the $1^{\text {st }}$ harvest was rather good even without mineral fertilizers. As the rates of organic lake sediments were increased, the yield of perennial grass (feed units) also increased from 4416 to 5357 (background without mineral fertilizers) and from 4929 to 6284 feed units (background with minimal rates of mineral fertilizers) respectively. Fertilization with $65 \mathrm{t} \mathrm{ha}^{-1}$ of manure resulted the same yield as the fertilization with the mixture of $10 \mathrm{t} \mathrm{ha}^{-1}$ sediments plus $10 \mathrm{tha}^{-1}$ manure.

The yield of feed units of perennial grass was larger in the $2^{\text {nd }}$ harvest than in the $1^{\text {st }}$ one, though the additional yields were similar. On both backgrounds of mineral fertilization they increased from 3111 to 3550 and from 3755 to 4063 of feed units and the yield of $3^{\text {rd }}$ grass were bigger and reached 3276-6930 and 4952-7560 feed units depending on the applied rates of sediments. Having applied manure, the yield was obtained the one of similar to control treatments. Whereas the application of sedimentsmanure and sediments-sewage mixtures produced the same yields as fertilization with pure sediments.

Dry summer of 2004 affected particularly negatively the yield of winter rye cultivated after perennial grass of $1^{\text {st }}$ and $2^{\text {nd }}$ year of use. Grain developed badly and was small. The yield did not reach even $2 \mathrm{t} \mathrm{ha}^{-1}$. If we compare the yield of control treatments of both backgrounds we will see that mineral $\mathrm{N}_{40} \mathrm{P}_{30} \mathrm{~K}_{50}$ fertilizers did not help much. However, they were better affected by applied organic fertilizers and, thus, their yield of grain and straw increased for about 100-600 feed units. Yield of blend of oats and lupine on both background depended from the all of applied rates of organic lake sediments and increased from 6128 to 8744 and 6192 to 13248 feed units.

The sum of feed units during the crop rotation of 11 years shows that the rates of organic sediments increased the yield by $3-33 \%$. However, the mixture of $10 \mathrm{t} \mathrm{ha}^{-1}$ sediments plus 25 tha $^{-1}$ manure was most effective on both backgrounds of mineral fertilization. It reliably increased the yield by 22 and $26 \%$. A rather large and reliable additional yield (24\%) was obtained on the background without mineral fertilizers having applied the largest $\left(40 \mathrm{t} \mathrm{ha}^{-1}\right)$ sediments rate. The effect of manure was the same as the effect of applied lower rates of sediments and sediments-manure mixture. 
Table 1. The effect of organic sediment on the yield on feed units of crop rotation

\begin{tabular}{|c|c|c|c|c|c|c|c|c|c|c|c|c|c|}
\hline \multirow[b]{2}{*}{$\begin{array}{c}\text { TREAT- } \\
\text { MENTS OF } \\
\text { TRIAL }\end{array}$} & \multicolumn{11}{|c|}{ YIELD OF FEED UNITS } & \multicolumn{2}{|c|}{$\begin{array}{c}\text { TOTAL FEED } \\
\text { UNITS }\end{array}$} \\
\hline & $\begin{array}{l}\text { MAIZE } \\
1999\end{array}$ & $\begin{array}{c}\text { MAIZE } \\
2000\end{array}$ & $\begin{array}{l}\text { BARLE } \\
\text { Y2001 }\end{array}$ & $\begin{array}{c}\text { PERE- } \\
\text { NNIAL } \\
\text { GRASS } \\
1^{\text {ST }} \\
\text { HARVE } \\
\text { ST 2002 } \\
\end{array}$ & $\begin{array}{c}\text { PERE- } \\
\text { NNIAL } \\
\text { GRASS } \\
\mathbf{2}^{\text {ND }} \\
\text { HARVES } \\
\text { T2003 } \\
\end{array}$ & $\begin{array}{l}\text { WIN- } \\
\text { TER } \\
\text { RYE } \\
2004\end{array}$ & $\begin{array}{c}\text { BLEND } \\
\text { OF } \\
\text { OATS } \\
\text { AND } \\
\text { LUPINE } \\
2005 \\
\end{array}$ & $\begin{array}{c}\text { BARLEY } \\
2006\end{array}$ & $\begin{array}{c}\text { PERE- } \\
\text { NNIAL } \\
\text { GRASS } \\
3^{\text {RD }} \\
\text { HARVE } \\
\text { ST 2007 } \\
\end{array}$ & $\begin{array}{c}\text { BARLEY } \\
2008\end{array}$ & $\begin{array}{c}\text { BLEND } \\
\text { OF } \\
\text { OATS } \\
\text { AND } \\
\text { LUPIN } \\
\text { E2009 } \\
\end{array}$ & $\begin{array}{l}\text { OVER } \\
\text { ROTA- } \\
\text { TION }\end{array}$ & $\%$ \\
\hline \multicolumn{14}{|c|}{ BACKGROUND WITHOUT MINERAL FERTILIZERS } \\
\hline 1. CONTROL & 2170 & 1180 & 1888 & 4917 & 3245 & 1625 & 3428 & 1619 & 4536 & 1065 & 6128 & 31800 & 100 \\
\hline 2. $10 \mathrm{~T} \mathrm{HA}^{-1} \mathrm{~S}$ & 2188 & 1416 & 1943 & 4416 & 3111 & 1977 & 2783 & 1766 & 3276 & 1129 & 8336 & 32341 & 102 \\
\hline 3. $20 \mathrm{~T} \mathrm{HA}^{-1} \mathrm{~S}$ & 2520 & 1302 & 2084 & 4656 & 3254 & 1830 & 3075 & 1958 & 4064 & 1257 & 8344 & 34344 & 108 \\
\hline 4. $40 \mathrm{~T} \mathrm{HA}^{-1} \mathrm{~S}$ & 3255 & 1386 & 2120 & $\mathbf{5 3 5 7}$ & 3550 & 2113 & 3375 & 1961 & 6262 & 1376 & 8744 & 39499 & 124 \\
\hline $\begin{array}{l}5.10 \mathrm{~T} \mathrm{HA}^{-1} \mathrm{~S} \\
+10 \mathrm{~T} \mathrm{HA}^{-1} \mathrm{M}\end{array}$ & 3010 & 1362 & 1821 & 4663 & 3256 & 2151 & 3015 & 1507 & 6930 & 1393 & 5368 & 34476 & 108 \\
\hline $\begin{array}{r}\text { 6. } 10 \mathrm{THA}^{-1} \mathrm{~S} \\
+25 \mathrm{~T} \mathrm{HA}^{-1} \mathrm{M}\end{array}$ & 3885 & 1582 & 2040 & 4908 & 3503 & 2394 & 3113 & 1771 & 7069 & 1605 & 8296 & 40165 & 126 \\
\hline $\begin{array}{l}\text { 7. } 10 \mathrm{~T} \mathrm{HA}^{-1} \mathrm{~S} \\
+10 \mathrm{M}^{3} \mathrm{SE}\end{array}$ & 2800 & 1355 & 1987 & 4212 & 3314 & 2090 & 3540 & 1872 & 5166 & 1172 & 4808 & 32316 & 102 \\
\hline 8. $65 \mathrm{~T} \mathrm{HA}^{-1} \mathrm{M}$ & 3255 & 1489 & 1920 & 4496 & 3202 & 2102 & 3158 & 1496 & 4253 & 1165 & $\mathbf{5 8 0 0}$ & 32335 & 102 \\
\hline $\mathbf{L S D}_{\mathbf{0 5} \%}$ & 853 & 286 & 848 & 1157 & 901 & 482 & 827 & 513 & 603 & 364 & 652 & 5169 & \\
\hline \multicolumn{14}{|c|}{ BACKGROUND OF MINIMAL RATES OF MINERAL FERTILIZERS } \\
\hline 1. CONTROL & 2065 & 1908 & 3280 & 4929 & 3925 & 1724 & 4178 & 3912 & 5122 & 1803 & 6192 & 39037 & 100 \\
\hline 2. $10 \mathrm{~T} \mathrm{HA}^{-1} \mathrm{~S}$ & 2695 & 1439 & 3728 & 5423 & 3755 & 2436 & 3825 & 3990 & 4952 & 1918 & 9216 & 43377 & 111 \\
\hline 3. $20 \mathrm{~T} \mathrm{HA}^{-1} \mathrm{~S}$ & 3133 & 1472 & 4525 & 5858 & 4121 & 2325 & 3825 & 4286 & 6577 & 2017 & 8432 & 46571 & 119 \\
\hline 4. $40 \mathrm{~T} \mathrm{HA}^{-1} \mathrm{~S}$ & 3028 & 1736 & 4021 & 5865 & 4063 & 2508 & 4335 & 4058 & 6728 & 2243 & 13248 & 51833 & 133 \\
\hline $\begin{array}{l}\text { 5. } 10 \mathrm{~T} \mathrm{HA}^{-1} \mathrm{~S} \\
+10 \mathrm{TH}^{-1} \mathrm{M}\end{array}$ & 3255 & 1743 & 3554 & 5189 & 3559 & 2315 & 3660 & 3892 & 7560 & 2031 & 10696 & 47454 & 122 \\
\hline $\begin{array}{r}\text { 6. 10T HA } \mathrm{HA}^{-1} \mathrm{~S} \\
+25 \mathrm{~T} \mathrm{HA}^{-1} \mathrm{M}\end{array}$ & 4113 & 1946 & 4071 & 5379 & 4061 & 2667 & 4020 & 3749 & 5928 & 1984 & 9808 & 47726 & 122 \\
\hline $\begin{array}{c}\text { 7. } 10 \mathrm{~T} \mathrm{HA}^{-1} \mathrm{~S} \\
+10 \mathrm{M}^{3} \mathrm{SE}\end{array}$ & 3220 & 1785 & 3929 & 6284 & 4105 & 2739 & 4365 & 3680 & 7686 & 2150 & 7424 & 47367 & 121 \\
\hline 8. $65 \mathrm{~T} \mathrm{HA}^{-1} \mathrm{M}$ & 3098 & 1925 & 3945 & 4928 & 3791 & 2341 & 4133 & 3766 & 5298 & 1902 & 6096 & 41223 & 106 \\
\hline $\mathbf{L S D}_{\mathbf{0 5} \%}$ & 725 & 428 & 798 & 1349 & 1367 & 205 & 1000 & 714 & 988 & 378 & 1317 & 3234 & \\
\hline
\end{tabular}


While analysing the efficiency of the interaction of various sediments rates and its mixtures with other fertilizers it was determined that the yield of feed units in crop rotation depended upon the parameters of soil acidity (Table 2), when mineral N3060P30-40K50-60 fertilizers were applied for background fertilization and without these fertilizers.

Strong correlation connection $(\mathrm{r} 2=0.68, \mathrm{Sr}=0.12)$ was determined between the quantity of feed units in crop rotation and parameters of soil acidity. The yield obtained on the background without mineral fertilizers had a strong correlation connection $(\mathrm{r} 2=$ $0.51, \mathrm{Sr}=0.15$ ) with the amounts of nitrogen, phosphorus, and potassium naturally present in soil or inserted with organic fertilizers. Fertilization of soil with minimal rates of mineral NPK fertilizers insured only medium correlation connection $(\mathrm{r} 2=0.38, \mathrm{Sr}=$ 0.17 ) between the yield of crop rotation and the quantity of nutrients in soil.

Table 2. Relationship between feed units of rotation and soil $\mathrm{pH}\left(x_{1}\right)$, hydrolytic acidity $(H$ mekv/kg soil $\left.-x_{2}\right)$, absorbed bases (S mekv/kg soil $\left.-x_{3}\right)$, and the amounts of nitrogen $\left(N \%-x_{4}\right)$, active phosphorus $\left(\mathrm{P}_{2} \mathrm{O}_{5} \mathrm{mg} / \mathrm{kg}\right.$ soil.- $\left.x_{5}\right)$, active potassium $\left(\mathrm{K}_{2} \mathrm{O} \mathrm{mg} / \mathrm{kg}\right.$ soil.- $\left.x_{5}\right)$

\begin{tabular}{c|c|r|c}
\hline $\begin{array}{c}\text { Agrochemical } \\
\text { properties }\end{array}$ & Regression equation & $\boldsymbol{r}^{2}$ & $\boldsymbol{S} \boldsymbol{r}$ \\
\hline \multicolumn{3}{|c|}{ Background without mineral fertilizers } \\
$\mathrm{pH}, \mathrm{H}, \mathrm{S}$ & $\mathrm{y}=7465.53+31.81 \mathrm{x}_{1}+498.80 \mathrm{x}_{2}+9.67 \mathrm{x}_{3}$ & 0.68 & 0.12 \\
$\mathrm{~N}, \mathrm{P}_{2} \mathrm{O}_{5}, \mathrm{~K}_{2} \mathrm{O}$ & $\mathrm{y}=7879.47+197184.64 \mathrm{x}_{4}-35.93 \mathrm{x}_{5}-18.38 \mathrm{x}_{6}$ & 0.52 & 0.15 \\
\multicolumn{3}{|c|}{ Background of minimal rates of mineral NPK fertilizers } \\
$\mathrm{pH}, \mathrm{H}, \mathrm{S}$ & $\mathrm{y}=-17490.14+475.02 \mathrm{x}_{1}+694.85 \mathrm{x}_{2}-7.99 \mathrm{x}_{3}$ & 0.68 & 0.12 \\
$\mathrm{~N}, \mathrm{P}_{2} \mathrm{O}_{5}, \mathrm{~K}_{2} \mathrm{O}$ & $\mathrm{y}=26194.07-2253.51 \mathrm{x}_{4}-53.00 \mathrm{x}_{5}+22.92 \mathrm{x}_{6}$ & 0.38 & 0.17 \\
\hline
\end{tabular}

Note: in this table the probability level is $95 \%$

Since soil acidity was neutral before the establishment of experimental plots and the amount of calcium was low in the investigated sediments the soil acidity did not change, after 11 years of crop rotation, on the background without mineral fertilizers- $\mathrm{pH}$ remained almost the same (Table 3). The exchangeable bases also increased from 104.8 to 228.8 mequiv $\mathrm{kg}^{-1}$ of soil.

On the background with mineral fertilizers, when soil was fertilized with various rates of sediments, mixtures of $10 \mathrm{t} \mathrm{ha}^{-1}$ sediments plus $25 \mathrm{t} \mathrm{ha}^{-1}$ manure, and $10 \mathrm{t} \mathrm{ha}^{-1}$ sediments plus $10 \mathrm{~m}^{3}$ sewage, the soil acidity changed from rather neutral into rather acid. Soil $\mathrm{pH}$ changed from 6.5 to 5.7 , the exchangeable bases decreased from 108.4 to 97.0 mequiv $\mathrm{kg}^{-1}$. After fertilization with manure on both backgrounds soil $\mathrm{pH}$ and the exchangeable bases of soil increased by 84.9-92.6 mequiv $\mathrm{kg}^{-1}$.

Fertilization of soil with various rates of sediments, its mixtures and manure influenced a little bit the amount of total nitrogen. This parameter changed very slightly. However, after fertilization with mineral NPK fertilizers, in all treatments the amount of total nitrogen increased by $0.003-0.013 \%$ units. 
Table 3. Effect of lake sedoiments to the agrochemical indices in Sandy Loam Cambisol

\begin{tabular}{|c|c|c|c|c|c|c|}
\hline \multirow[t]{2}{*}{ Treatments } & \multirow[t]{2}{*}{$\mathbf{p H}_{\mathrm{KCl}}$} & \multirow{2}{*}{$\begin{array}{l}\text { Exchange- } \\
\text { able bases, } \\
\text { mquiv kg }\end{array}$} & Total N & $\begin{array}{c}\text { Organic } \\
\text { carbon }\end{array}$ & $\mathbf{P}_{2} \mathbf{O}_{5}$ & $\mathbf{K}_{2} \mathbf{O}$ \\
\hline & & & \multicolumn{2}{|c|}{$\%$} & \multicolumn{2}{|c|}{$\mathrm{mg} \mathrm{kg}^{-1}$ of soil } \\
\hline \multicolumn{7}{|c|}{ Background without mineral fertilizers } \\
\hline \multirow{2}{*}{ 1. Control } & $6.4^{*}$ & 106.5 & 0.087 & 1.58 & 176 & 191 \\
\hline & $6.8 * *$ & 148.4 & 0.093 & 1.59 & 158 & 159 \\
\hline \multirow{2}{*}{ 2. $10 \mathrm{tha}^{-1} \mathrm{~S}$} & 6.4 & 174.8 & 0.091 & 1.56 & 188 & 170 \\
\hline & 7.1 & 153.2 & 0.087 & 1.53 & 158 & 138 \\
\hline \multirow{2}{*}{ 3. $20 \mathrm{t} \mathrm{ha}^{-1} \mathrm{~S}$} & 6.6 & 137.0 & 0.087 & 1.62 & 179 & 182 \\
\hline & 7.0 & 110.0 & 0.100 & 1.75 & 147 & 135 \\
\hline \multirow{2}{*}{ 4. $40 \mathrm{tha}^{-1} \mathrm{~S}$} & 6.4 & 122.5 & 0.094 & 1.54 & 180 & 179 \\
\hline & 6.8 & 136.9 & 0.093 & 1.64 & 156 & 130 \\
\hline 5. $10 \mathrm{tha}^{-1} \mathrm{~S}+10 \mathrm{tha}^{-1}$ & 6.7 & 148.6 & 0.089 & 1.70 & 189 & 184 \\
\hline $\mathrm{M}$ & 7.0 & 201.5 & 0.083 & 1.55 & 156 & 142 \\
\hline 6. $10 \mathrm{tha}^{-1} \mathrm{~S}+25 \mathrm{tha}^{-1}$ & 6.3 & 108.8 & 0.090 & 1.81 & 152 & 172 \\
\hline $\mathrm{M}$ & 6.5 & 106.0 & 0.087 & 1.64 & 149 & 131 \\
\hline \multirow{2}{*}{ 7. $10 \mathrm{tha}^{-1} \mathrm{~S}+10 \mathrm{~m}^{3} \mathrm{Se}$} & 6.5 & 150.1 & 0.090 & 1.62 & 174 & 178 \\
\hline & 7.1 & 243.1 & 0.087 & 1.60 & 176 & 156 \\
\hline \multirow{2}{*}{ 8. $65 \mathrm{t} \mathrm{ha}^{-1} \mathrm{M}$} & 6.4 & 133.9 & 0.084 & 1.55 & 183 & 190 \\
\hline & 7.2 & 157.1 & 0.080 & 1.56 & 146 & 156 \\
\hline \multirow{2}{*}{$\mathrm{LSD}_{05 \%}$} & 0.47 & 104.8 & 0.010 & 0.24 & 61,3 & 33,7 \\
\hline & 0.72 & 166.5 & 0.014 & 0.18 & 47.1 & 47.0 \\
\hline \multicolumn{7}{|c|}{ Background of minimal rates of mineral NPK fertilizers } \\
\hline \multirow{2}{*}{ 1. Control } & $6.4^{*}$ & 106.5 & 0.087 & 1.58 & 176 & 191 \\
\hline & $6.9 * *$ & 116.7 & 0.090 & 1.67 & 169 & 189 \\
\hline \multirow{2}{*}{ 2. $10 \mathrm{tha}^{-1} \mathrm{~S}$} & 6.4 & 174.8 & 0.091 & 1.56 & 188 & 170 \\
\hline & 6.7 & 162.4 & 0.088 & 1.60 & 152 & 165 \\
\hline \multirow{2}{*}{ 3. $20 \mathrm{t} \mathrm{ha}^{-1} \mathrm{~S}$} & 6.6 & 137.0 & 0.087 & 1.62 & 179 & 182 \\
\hline & 6.3 & 98.6 & 0.103 & 1.65 & 124 & 142 \\
\hline \multirow{2}{*}{ 4. $40 \mathrm{tha}^{-1} \mathrm{~S}$} & 6.4 & 122.5 & 0.094 & 1.54 & 180 & 179 \\
\hline & 6.5 & 89.4 & 0.102 & 1.80 & 146 & 203 \\
\hline 5. $10 \mathrm{tha}^{-1} \mathrm{~S}+10 \mathrm{tha}^{-1}$ & 6.7 & 148.6 & 0.089 & 1.70 & 189 & 184 \\
\hline $\mathrm{M}$ & 6.9 & 158.0 & 0.092 & 1.63 & 183 & 185 \\
\hline 6. $10 \mathrm{tha}^{-1} \mathrm{~S}+25 \mathrm{tha}^{-1}$ & 6.3 & 108.8 & 0.090 & 1.81 & 152 & 172 \\
\hline $\mathrm{M}$ & 6.1 & 69.6 & 0.105 & 1.76 & 138 & 138 \\
\hline \multirow{2}{*}{ 7. $10 \mathrm{tha}^{-1} \mathrm{~S}+10 \mathrm{~m}^{3} \mathrm{Se}$} & 6.5 & 150.1 & 0.090 & 1.62 & 174 & 178 \\
\hline & 6.4 & 185.5 & 0.100 & 1.82 & 165 & 165 \\
\hline 8.65 & 6.4 & 133.9 & 0.084 & 1.55 & 183 & 190 \\
\hline $\mathrm{t} \mathrm{ha}^{-1} \mathrm{M}$ & 6.8 & 104.2 & 0.098 & 1.80 & 192 & 192 \\
\hline \multirow{2}{*}{$\mathrm{LSD}_{05 \%}$} & 0.47 & 104.8 & 0.010 & 0.24 & 61.3 & 33.7 \\
\hline & 1.00 & 137.6 & 0.020 & 0.36 & 82.6 & 86.6 \\
\hline
\end{tabular}

Note: $*_{-}$indicators before experiments in 1999; ** - indicators after crop rotation in 2009

On the background without mineral fertilizers higher content of humus $(1.71 \%)$ was found in soil fertilized with the highest rate of sediments. In other fertilization treatments higher percentage of humus was detected due to the impact of mineral nitrogen.

Small amount of phosphorus $(0.04 \%)$ was detected in organic sediments, therefore a little amount of phosphorus reached the soil. Fertilization with mineral (non-organic) fertilizers made a larger effect on the alterations of mobile phosphorus. On the background without mineral fertilizers in almost all treatments the amount of phosphorus was smaller by $7.9-23.2 \mathrm{mg} \mathrm{kg}^{-1}$ to compare with its amount before the 
establishment of experimental plots; on the background with mineral fertilizers in almost all variants it was larger by $13.2-32.8 \mathrm{mg} \mathrm{kg}^{-1}$. Bigger amount of phosphorus was detected in soil previously fertilized with manure $\left(214.5 \mathrm{mg} \mathrm{kg}^{-1}\right.$ of soil) and with sediments -manure mixture (178.3-198.0 mg kg-1 of soil). Similarly, the amount of potassium in organic sediments was rather low, too.

Therefore, due to various ways of fertilization the amount of active potassium in soil changed similarly to that of phosphorus. On the background without mineral fertilizers (when organic fertilisers were applied) the defined amount of potassium (2.0-28.8 $\mathrm{mg}$ $\mathrm{kg}^{-1}$ of soil) was lower almost in all treatments than its amount before the establishment of an experimental plot. However, on the background with mineral fertilizers it was larger (2.0-32.3 mg kg-1 of soil) almost in all treatments. Different fertilization with organic fertilizers did not influence the amount of potassium in soil.

While analysing the impact of organic sediments upon the soil moisture, it could be observed that in 1999, 2003-2006 the indicators of moisture was lower in spring, and in 1997 it was lower in autumn (Fig. 1). In this experiment stronger influence was observed when fertilizing with sediments and sediments-manure mixture.

To compare with the impact made by the application of manure, the rate of $40 \mathrm{tha}^{-1}$ of sediments increased the moisture of soil by 1.12-1.57\% units. The effect of manure equalled the smaller rate of sediments $\left(10 \mathrm{tha}^{-1}\right)$.

Soil bulk density did not depend upon moisture. The data shows the tendency towards the decrease of this parameter only after fertilization with $40 \mathrm{t} \mathrm{ha}^{-1}$ sediments rate and sediments -manure mixture. Density varied from 1.27 to $1.41 \mathrm{mgm}^{3}$ only in certain periods, and just in autumn of the years 2003, 2004 and 2007 it was a little bit lower (1.19-1.26 $\left.\mathrm{mgm}^{3}\right)$. During those years the soil bulk density was lower to compare with the data of spring investigations, but in 1999-2002 and 2009 on the contrary, the density was higher in autumn. The soil particle density was not investigated in this experiment because it changes insignificantly under the impact of anthropogenic factors and time.

Porosity directly depends upon the soil density. With the decrease of density the porosity increases. It is evidently proved by the research results.

In 1999-2001 and 2005 total porosity of soil was higher in spring, after soil cultivation, and it decreased in autumn. However, in later years of crop rotation, when perennial grass and fall rye were cultivated, the parameters of total porosity were increasing in autumn. The highest (48.36-57.65 \%) total porosity was determined in soil fertilized with $40 \mathrm{t} \mathrm{ha}^{-1}$ organic sediments rate almost during the whole period of investigation. 
Soil humidity

$L S D_{05}-1.42-2.45$

$\%$

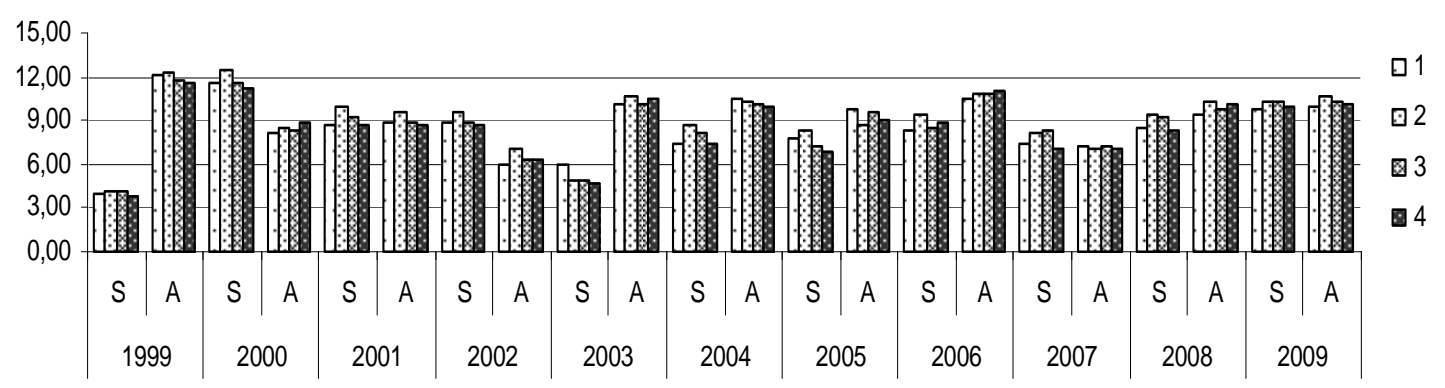

Soil bulk density

$\mathrm{mg} \mathrm{m}^{-3}$

$L S D_{05}-0.16-0.24$

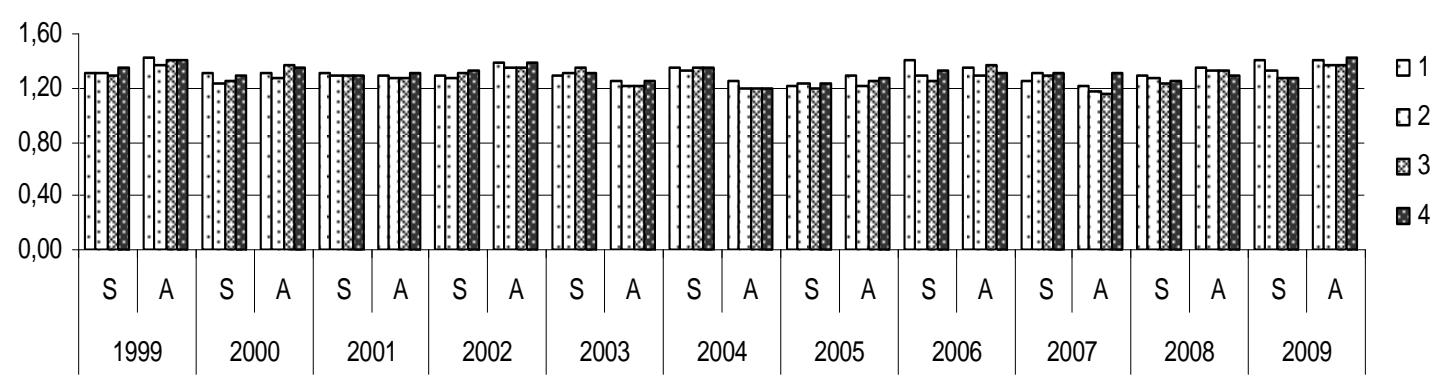

Soil total porosity

$L S D_{05}-5.29-7.79$

$\%$

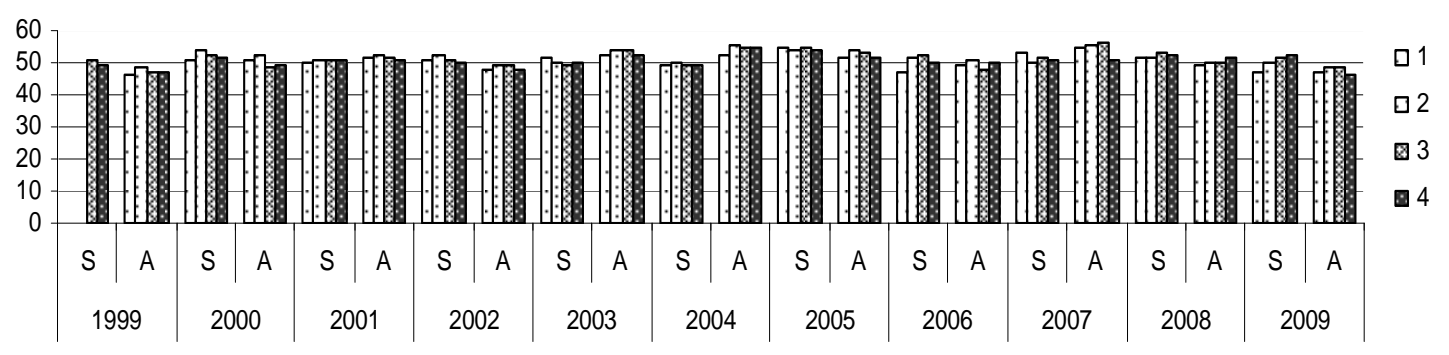

Figure 1. The effect of lakes sediments on sandy loam cambisols humidity, density and total porosity ( $S$ - spring, after sowing of crop; A-autumn, after harvesting; 1-4-treatments of trials:

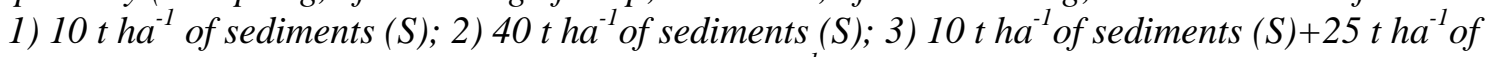
manure (M); 4) 65 tha of manure (M)

\section{Conclusions}

1. The application of various rates of organic lake sediments increased the yield by 4$20 \%$. The 40 tha $^{-1}$ sediments and mixture of 10 tha $^{-1}$ of sediments plus 25 tha $^{-1}$ of manure was more effective and reliably increased the yield by 22 and $25 \%$. The impact 
of manure was the same as the effect of smaller rates $\left(10,20 \mathrm{t} \mathrm{ha}^{-1}\right)$ of sediments and sediments-manure mixture.

2. The yield of feed units strongly correlated with the indicators of soil acidity and amounts of nitrogen, phosphorus, and potassium present in the soil and introduced with organic fertilisers.

3. Variuos rates of organic lake sediments used for soil fertilization did not change soil acidity. Depending on fertilization of $40 \mathrm{tha}^{-1}$ sediments the amount of total nitrogen and humus increased The amounts of phosphorus and potassium were decreased. The $40 \mathrm{t} \mathrm{ha}^{-1}$ lake organic sediments rate was most efficient.

4. The application of lake sediments produced a positive effect on the physical properties of sandy loam soil. The lake sapropel increased soil moisture and porosity and reduced its bulk density.

\section{REFERENCES}

[1] Adriaens, P., Batterman, S., Blum, J., Hayes, K., Meyers, P., Weber, W. (2002): Great Lakes Sediment: Contamination, Toxicity and Beneficial. - Re-Use, SNRE, pp: 37.

[2] Alkan, H., Korkmaz, M., Altunbas, S. (2009): Interactions Between Local People and Lakes: an Example from Turkey. - J. Environ. Eng. Landscape Manage 17(3): Ia-Ih.

[3] Andresini, A., Loiacono, F., De Marco, A., Spangoli, F. (2003): Recent Sedimentation and Present Enviromental State of "Lesina lake". - Proceedings of the International Conference on Southern European coastal lagoons: The Influence of River Basin-Coastal Zone Interactions. Perrara, Italy. pp: 51.

[4] Askinazi, D.L. (1975): The methods for determination of liming needs of soddy-podzolic soils. - The agro-chemical methods of soil investigation (in Russian) Nauka, Moscow, pp: 228-243.

[5] Bakšiene, E., Janušiene, V. (2005): The effects of calcareous sapropel applicationon the changes of Haplic Luvisols chemical propertiesand crop yield. - Plant, Soil and Environment. Dev. 51(12): 539-544.

[6] Booth, C.A., Baksiene, E., Fullen, M.A., Ciunys, A. (2007): Long-term agrochemical dynamics: engineering, application and challenges of calcareous sapropel as a soil fertilizer. - International Journal of Ecodynamics Dev. 2: 108-116.

[7] Brewbaker, J.L. (1995): Experimental design on a spreadsheet University of Hawaii. Honolulu. HI, pp: 175.

[8] Egner, H., Riehm, H., Domingo, W.R. (1960): Egner H Riehm H \& Domingo WR Untersuchungen über die chemische Bodenanalyse als Grundlage für die Beurteilung des Nährstoffzustandes der Böden. II. Chemische Extractionsmethoden zur Phospor- und Kaliumbestimmung. - Annals Royal Agricultural College, Sweden. 26: 199-215.

[9] Enters, D., Walter Dörfler, W., Zolitschka, B. (2008): Historical soil erosion and land-use change during the last two millennia recorded in lake sediments of Frickenhauser See, northern Bavaria, central Germany. - The Holocene 18: 243-254.

[10] Grigorov, M.S., Ovchinnikov, A.S. (1994): Utilization of Volga-Akhtuba flooplain sapropel. - Pochvovedenie, Dev. 0-5: 62-66.

[11] Grishina, L.A., Kurmisheva, N.A., Kazakova, S.V., Moroz, O.R. (1990): The effect of overwashing of sapropel fertilizers on agrochemical propeties and humus status of soddygley soil. - Moscow University soil science bulletin. Dev. 45-2: 62-69.

[12] Loveland, P., Webb, J. (2003): Is there a critical level of organic matter in the agricultural soils of temperate regions: a review. - Soil and Tillage Research. Dev. 70 1: 1-18.

[13] Moore, J.E., Undersander, D.J. (2002): Relative forage quality: an alternative to relative feed value and quality index. - Proceedings 13th Annual Florida Ruminant Nutrition Symposium in Jan, pp: 16-32. 
[14] Orlov, D.S, Grishina L.A. (1981): Practical work in humus chemistry (in Russian). Moscow State university, Moscow, pp: 272.

[15] Orlov, D.S., Sadovnikova, L.K. (1996): Nontraditional ameliorants and organic fertilizer. - Euroasian soil science. Dev. 29-4: 474-479.

[16] Roberts, N., Brayshaw, D., Kuzucuoglu, C., Perez, R., Sadori, L. (2011): The midHolocene climatic transition in the Mediterranean: Causes and consequences. - The Holocene 21: 3-13.

[17] Roberts, N., Eastwood, W.J., Kuzucuoglu, C., Florentino, G., Caracuta, V. (2011): Climatic, vegetation and cultural change in the eastern Mediterranean during the midHolocene environmental transition. - The Holocene 21: 147-162.

[18] Shukla, S., Boman, B.J., Ebel, R.C., Roberts, P.D., Hanlon, E.A. (2010): Reducing Unavoidable Nutrient Losses from Florida's Horticultural Crops. - Hort Technology 20: 52-66.

[19] Tarakanovas, P., Raudonius, S. (2003): The statistical analysis of data of agricultural researches applying computers programs ANOVA, STAT, SPLIT-PLOT from a package selection and IRRISTAT. (in Lithuanian). - Academy, pp: 57.

[20] Trapeznikova, O.N. (2011): Environmental limitations on agricultural development of the forest zone of the East European Plain (Russian Federation). - Geological Society, London, Special Publications 352: 11-26. 